\title{
Numerical investigation of penetration of a large-diameter footing into normally consolidated kaolin clay with a consolidation phase
}

\author{
D. WANG* and B. BIENEN +
}

\begin{abstract}
Jack-up installation is typically discontinuous with seawater ballast being taken on and shed again periodically to elevate the hull out of the ocean as the spudcan footings penetrate the soil. Any pauses in the footing penetration provide the opportunity for consolidation to occur in sufficiently permeable cohesive soils. The undrained shear strength underneath the spudcan is increased during consolidation, which enhances the penetration resistance within a limited extent immediately after the consolidation. This phenomenon has been explored in a limited number of centrifuge tests, but cannot be reproduced using conventional finite-element methods. An effective stress large-deformation finiteelement approach based on periodic mesh regeneration is employed to capture the entire process of 'penetration-consolidation-penetration', with the modified Cam-clay model being incorporated to represent the behaviour of normally consolidated kaolin clays. The numerical model established is verified by comparison with two series of centrifuge tests before exploring the influence of key parameters, including consolidation depth, consolidation duration, coefficient of consolidations, anisotropy of permeability and loads held during consolidation. The normalised consolidation duration is identified as the dominant factor that affects the post-consolidation peak in penetration resistance. A simple method is proposed to estimate the post-consolidation penetration resistance.
\end{abstract}

KEYWORDS: bearing capacity; clays; consolidation; finite-element modelling; footings/foundations; offshore engineering

\section{INTRODUCTION}

Prior to the installation of a mobile offshore jack-up platform at a site, the load-penetration curve is required to be predicted. Typically bearing capacity theory is used at a series of embedment depths, with the soil response assumed to be drained in sand and undrained in clay (ISO, 2012). However, jack-up installation typically is a discontinuous process, with any pauses providing the opportunity for consolidation to occur in sufficiently permeable cohesive soils (such as silty clays and clayey silts), which results in a zone of increased strength of the soil and then an enhancement in the penetration resistance. Brennan et al. (2006) reported such 'set-up' behaviour even for relatively short durations of preloading holds of around $3 \sim 4 \mathrm{~h}$. The penetrationconsolidation-penetration response of spudcan footings has to date been investigated in experiments performed in centrifuges at the University of Western Australia (UWA, Barbosa-Cruz, 2007; Bienen \& Cassidy, 2013; Stanier et al., 2014; Bienen et al., 2015). The existing centrifuge tests have limitations, as follows. (a) The load during the consolidation stage was maintained as the penetration resistance at the beginning of consolidation, which may not represent all practical scenarios. (b) The soil samples prepared were isotropic in permeability, while the permeability ratios of in-field

Manuscript received 9 March 2015; revised manuscript accepted 25 May 2016. Published online ahead of print 1 July 2016.

Discussion on this paper closes on 1 April 2017, for further details see p. ii.

* Shandong Provincial Key Laboratory of Marine Environment and Geological Engineering, Ocean University of China, Qingdao, Shandong, China; formerly Centre for Offshore Foundation Systems, University of Western Australia, Perth, WA, Australia.

$\dagger$ Centre for Offshore Foundation Systems, University of Western Australia, Perth, WA, Australia. naturally deposited sediments usually range between 1 and 5 (Vessia et al., 2012).

In this note, the entire 'penetration-consolidationpenetration' process of a spudcan in permeable clayey soil is investigated using a large-deformation finite-element (LDFE) method based on frequent mesh regeneration. The numerical model is validated by comparing with centrifuge tests of Purwana (2006) and Bienen \& Cassidy (2013) for different kaolin clays. Further study is conducted to explore the effects of several key factors which are not covered in the previous tests. A simplified method for predicting the post-consolidation penetration resistance is proposed.

\section{METHODOLOGY}

The 'penetration-consolidation-penetration' of spudcan footings was investigated using an axisymmetric LDFE approach, remeshing and interpolation technique with small strains (RITSS), incorporating the modified Cam-clay (MCC) model. The details of the RITSS for coupled effective stress-pore pressure problems can be found in Wang et al. $(2010,2013,2015)$. The soil close to the spudcan undergoes extreme and sudden changes in geometry in the very early stages of the installation process. To ensure computational convergence in the early stages of the LDFE analysis, the spudcan was pre-embedded at a shallow depth, $\sim 0.6 D$, where $D$ is the spudcan diameter. This was shown not to affect the results as sufficient penetration $(0 \cdot 3 D$ minimum $)$ preceded the consolidation stage. During consolidation, the load imposed on the spudcan was held constant as a fraction $\alpha$ of the resistance at the end of the first penetration stage. The shafted spudcan-soil interaction was simulated with frictionless contact (frictional contact yielded only slightly higher results). Drainage was permitted only at the soil surface. The soil horizontal and vertical dimensions were 
Table 1. Parameters of clays used in centrifuge tests

\begin{tabular}{l|c|c}
\hline Property & $\begin{array}{c}\text { Malaysian } \\
\text { kaolin clay }\end{array}$ & $\begin{array}{c}\text { UWA } \\
\text { kaolin clay }\end{array}$ \\
\hline Angle of internal friction, $\phi^{\prime}$ : degrees & 23 & 23 \\
Void ratio at $p^{\prime}=1 \mathrm{kPa}$ on virgin & $2 \cdot 35$ & $2 \cdot 25$ \\
$\quad$ consolidated line, $e_{\mathrm{N}}$ & $0 \cdot 244$ & $0 \cdot 205$ \\
Slope of normal consolidation line, $\lambda$ & $0 \cdot 053$ & $0 \cdot 044$ \\
Slope of swelling line, $\kappa$ & $0 \cdot 3$ & $0 \cdot 3$ \\
Poisson ratio, $v$ & 6 & 6 \\
Submerged unit weight: $\mathrm{kN} / \mathrm{m}^{3}$ & $1 \cdot 5$ & $2 \cdot 2$ \\
Soil sensitivity, $S_{\mathrm{t}}$ & & \\
\hline
\end{tabular}

taken as no less than $20 D$ to avoid boundary effects. The embedment depth of the spudcan was defined as the distance from the original soil surface to the lowest spudcan section with full diameter.

The UWA kaolin used in Bienen \& Cassidy (2013) was normally consolidated, whereas the Malaysian kaolin in Purwana (2006) featured undrained strength between 5 and $10 \mathrm{kPa}$ near the soil surface, owing to a surcharge applied during pre-consolidation of the sample at $1 \boldsymbol{g}$, where $\boldsymbol{g}$ is the acceleration of gravity. In the reproduction of Purwana et al. (2005) tests the whole soil was simplified as normally consolidated. The MCC parameters of both soils are provided in Table 1. The undrained shear strength at depth $z$ can be deduced from the MCC model (Wroth, 1984). The vertical permeability of the soil, $k_{\mathrm{v}}$, was expressed as function of the void ratio, as suggested in Mahmoodzadeh et al. (2014, 2015). Both kaolin samples are isotropic in permeability.

Significant research effort has been directed at demonstrating the effect of strain-softening and remoulding on the penetration resistance of penetrometers (e.g. Zhou \& Randolph, 2009) and spudcans (Hossain \& Randolph, 2009; Zhang et al., 2014). Hossain \& Randolph (2009) quantify this influence at $10-15 \%$. Zhang et al. (2014) illustrate separately the effect of large deformations (Fig. 1), comparing the wished-in-place results with those of ideal soil (soil sensitivity $\left.S_{\mathrm{t}}=1\right)$, and soil with strength degradation $\left(S_{\mathrm{t}}>1\right)$. The former is accounted for in this study through the LDFE technique. The MCC model, however, does not consider strain softening. Accounting for this well-documented strength degradation through a reduction of $10 \%$ of the resistance obtained using the MCC model with intact $s_{\mathrm{u}}$ yields bearing capacity factors similar to those reported in Zhang et al. (2014) and, importantly, as obtained in centrifuge experiments (Figs 2 and 5 below). The undrained strength related to disturbance can be recovered, at least partially, during long-term consolidation, hence the strength degradation effect is not applied to the response immediately post consolidation.

\section{COMPARISON WITH CENTRIFUGE TESTS \\ Tests by Purwana (2006)}

The centrifuge tests by Purwana (2006) were conducted at $100 \mathrm{~g}$. The spudcan diameter $D$ was $125 \mathrm{~mm}$ in model scale. The coefficient of consolidation of Malaysian kaolin was obtained from oedometer test results (C. F. Leung, personal communication, 2014), fitted as

$$
c_{\mathrm{v}}=5 \sigma_{\mathrm{v}}^{\prime 0.45}
$$

where the units of $c_{\mathrm{v}}$ and $\sigma_{\mathrm{v}}^{\prime}$ are $\mathrm{m}^{2} /$ year and $\mathrm{kPa}$, respectively. The undrained strength profile measured was $s_{\mathrm{u}}=1.44 z \mathrm{kPa}$, close to $1 \cdot 46 z \mathrm{kPa}$ from the MCC. $S_{\mathrm{t}}=1 \cdot 5$. A test with consolidation duration of 1.16 years and consolidation load ratio $\alpha=0.75$ at depth of $1.5 D$ was reproduced.

The numerical and experimental results are compared in Fig. 2. $F^{\prime}$ is the net penetration resistance, which represents

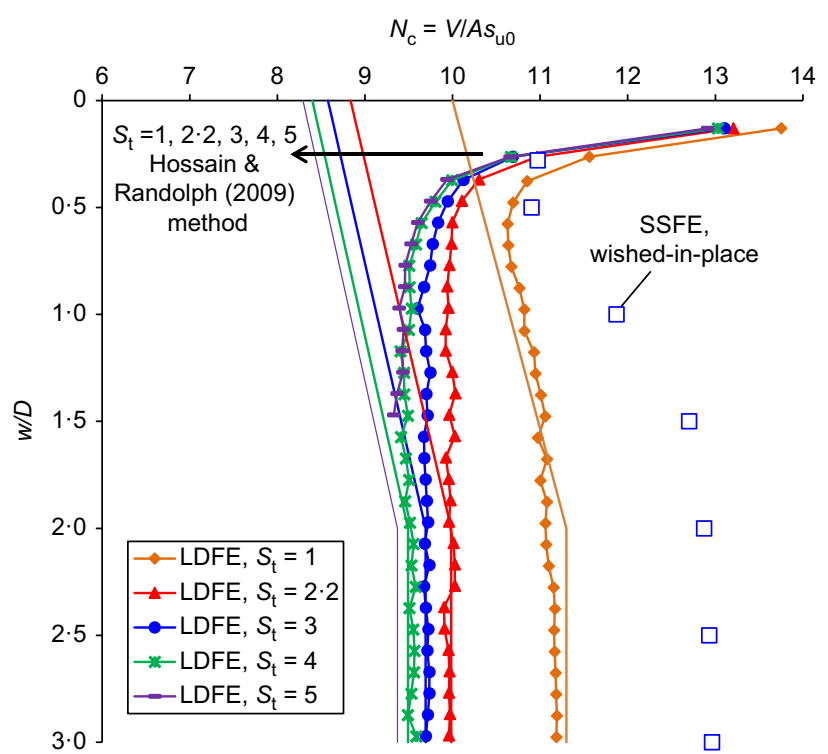

Fig. 1. Effects of large deformation and strength degradation on spudcan penetration resistance (Zhang et al., 2014)

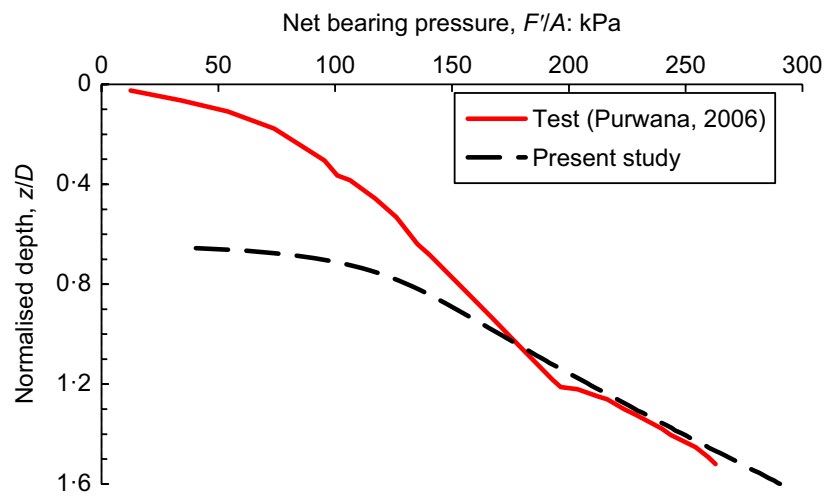

Fig. 2. Penetration capacity profile in Malaysian kaolin

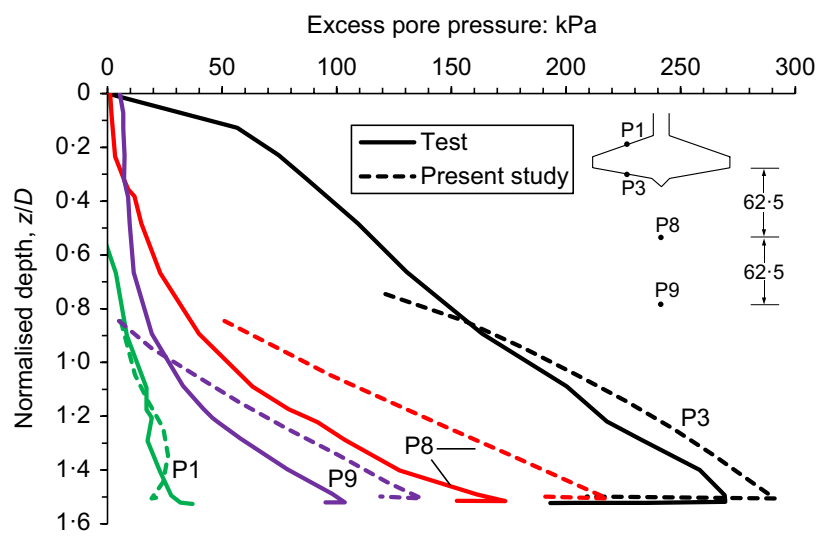

Fig. 3. Excess pore pressure accumulated during penetration and immediate unloading

the total force applied on the spudcan, $F$, subtracting the submerged weight of the spudcan in soil. Beyond the overconsolidated crust (experiments) and the initial embedment (numerical), the experimental curve matches well with that from the coupled LDFE approach.

The excess pore pressures at different positions are shown in Fig. 3. At mid-radius of the spudcan base (position P3), 


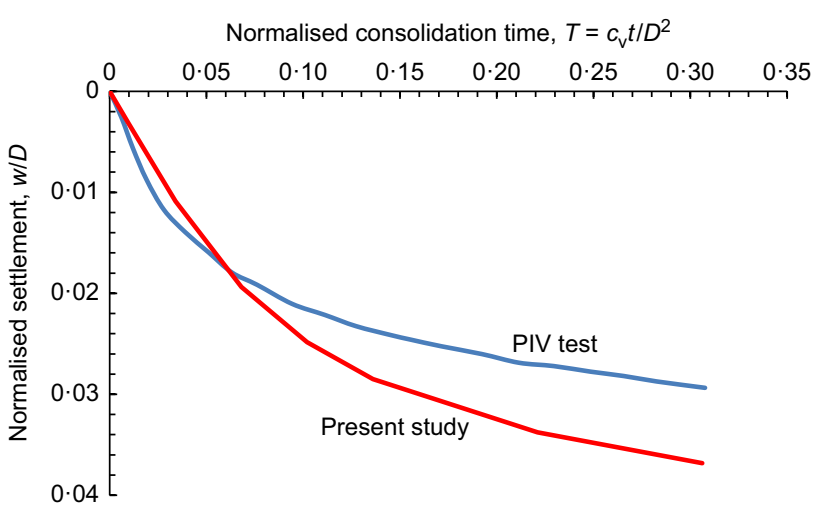

Fig. 4. Spudcan settlement during consolidation stage (consolidation depth $H \approx 1 \cdot 5 D$ )

both the numerical and experimental excess pore pressures increase nearly linearly with the penetration depth, achieving good agreement at $z / D>0.9$. The excess pore pressure on the spudcan top (position P1) is significantly lower compared with that on the spudcan base. It increases quickly as the load applied on the spudcan is reduced at the commencement of consolidation, owing to the slight upward movement caused by the unloading. The excess pore pressures predicted at positions P8 and P9 (buried under the spudcan tip at soil depths of $2 D$ and $2 \cdot 5 D$, respectively), are higher than those measured. The reason for this overestimation is unclear.

The final spudcan settlement induced by consolidation, as shown in Fig. 4, is predicted as 0.037D, which is $24 \%$ higher than the measured.

Tests by Bienen \& Cassidy (2013)

The coefficient of consolidation of UWA kaolin was (Richardson, 2007)

$$
c_{\mathrm{v}}=\sqrt{1+0 \cdot 14 \sigma_{\mathrm{v}}^{\prime}}
$$

An undrained strength gradient of $1 \cdot 1 \mathrm{kPa} / \mathrm{m}$ was obtained from three T-bar tests before any spudcan tests. Soil sensitivity measured was $2 \cdot 2$. An effective unit weight of $6 \mathrm{kN} / \mathrm{m}^{3}$ was assumed, hence $s_{\mathrm{u}}=1.46 z \mathrm{kPa}$ results from the MCC parameters. The spudcan was penetrated to a depth $H=1 D$ or $1 \cdot 5 \mathrm{D}$ and then the full load was held $(\alpha=1)$ for consolidation.

In Fig. 5, the capacity factor in this study achieves reasonable agreement with the experimental data. Load control in the centrifuge tests, especially during the early stages of consolidation, relies on feedback loops which may result in some load cycling and generation of additional excess pore pressures and settlement. It is therefore not surprising that the settlements predicted are smaller than those measured, as in Fig. 6.

The post-consolidation capacities and capacity factors predicted are shown in Fig. 7. The consolidation duration is normalised as

$$
T_{\mathrm{c}}=c_{\mathrm{v}} t_{\mathrm{c}} / D^{2}
$$

where $c_{\mathrm{v}}$ represents the value corresponding to the depth at the end of consolidation which is slightly larger than $H$. The soil underneath the spudcan undergoes reduction of void ratio during consolidation, the undrained shear strength is thus improved (Fig. 8). As a consequence, the post-consolidation resistance is enhanced sharply within a minimal penetration and then the resistance profile moves towards to the reference profile (without consolidation) gradually. This tendency can be observed more clearly in Fig. 7(b), in which the capacity factor is increased to a peak value and then reduced.

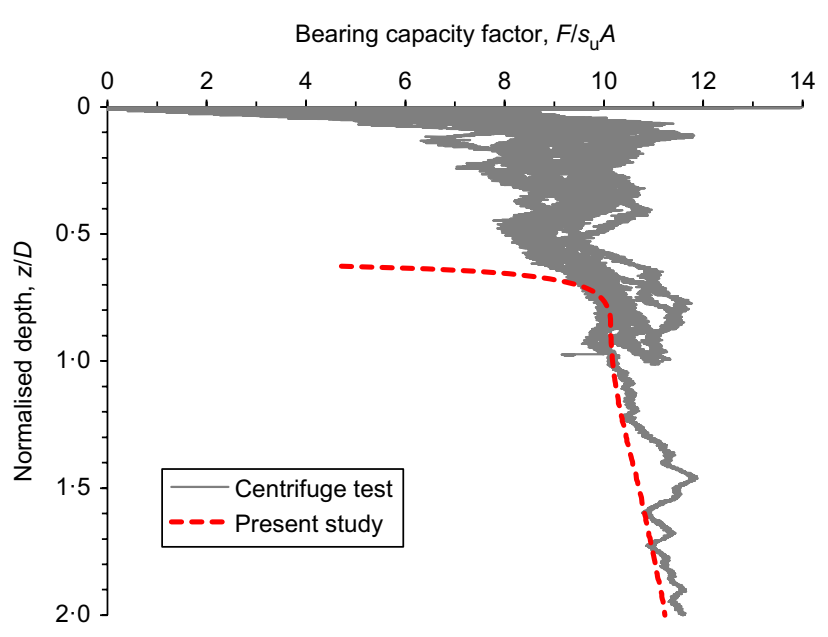

Fig. 5. Normalised penetration resistance in UWA kaolin

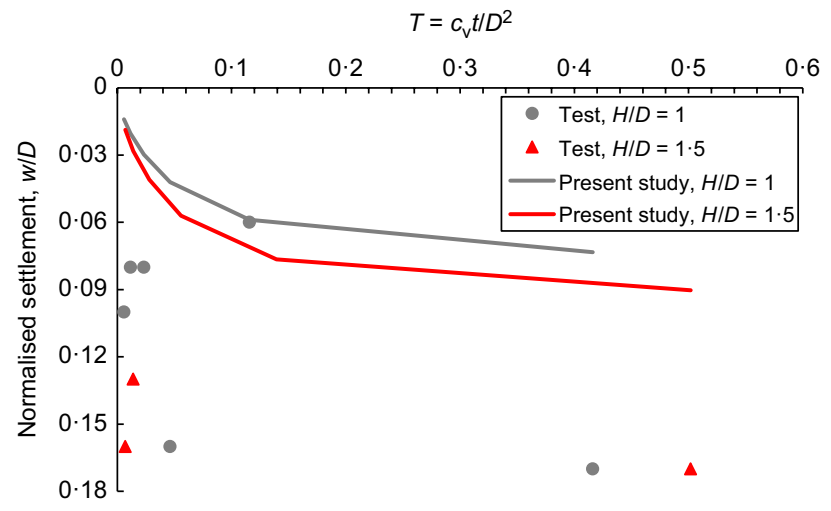

Fig. 6. Settlement during consolidation (UWA kaolin)

The effect of the consolidation duration on the postconsolidation resistance may be quantified through a ratio, termed peak ratio, $N_{\mathrm{cp}}^{*} / N_{\mathrm{cr}} . N_{\mathrm{cp}}^{*}$ is the peak capacity factor during post-consolidation penetration, and $N_{\mathrm{cr}}$ represents the capacity factor at the same depth on the reference profile accounting for strain softening (see Fig. 7(b)). The reference profile accounting for softening is obtained by reducing the numerical reference resistance by $10 \%$, as soil sensitivity is $\sim 2$. The predicted peak ratios are compared with three groups of centrifuge tests in Fig. 9. Both the experimental and numerical data highlight that the variation of the peak ratio with the normalised time depends insignificantly on the consolidation depth. The numerical predictions achieve reasonable agreement with the experimental results, although the trends with consolidation time differ moderately in their gradients. Neither set of data is perfect: on one hand, the centrifuge test results are affected by less than ideal load control, which is expected to have a stronger influence at shorter consolidation durations; the numerical analysis, on the other hand, essentially assumes remoulding of the soil is fully recovered during consolidation. Therefore, both may overestimate the peak ratio for short durations of consolidation (although for different reasons). Based on the LDFE analysis results and the above modelling considerations, a polyline is plotted in Fig. 9.

\section{INFLUENCES ON PEAK PENETRATION RESISTANCE}

The normalised consolidation duration and its influence on peak capacity factor is further explored numerically in terms of different soil permeabilities and consolidation load 


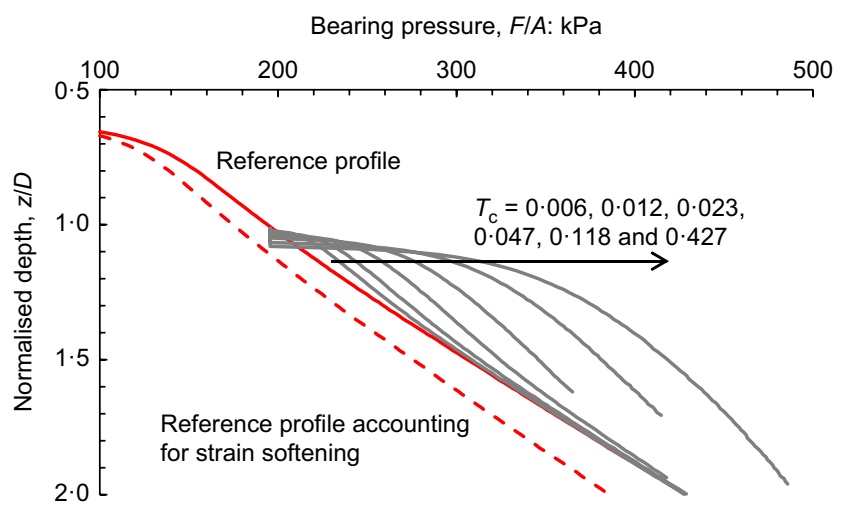

(a)

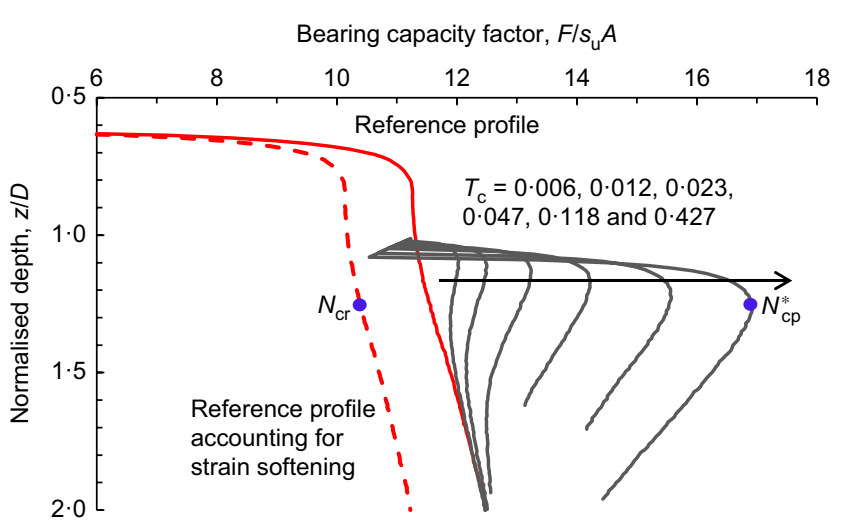

(b)

Fig. 7. Pressure and capacity factor during post-consolidation penetration (UWA kaolin, consolidation depth $H=1 D$ ): (a) penetration pressure; (b) capacity factor

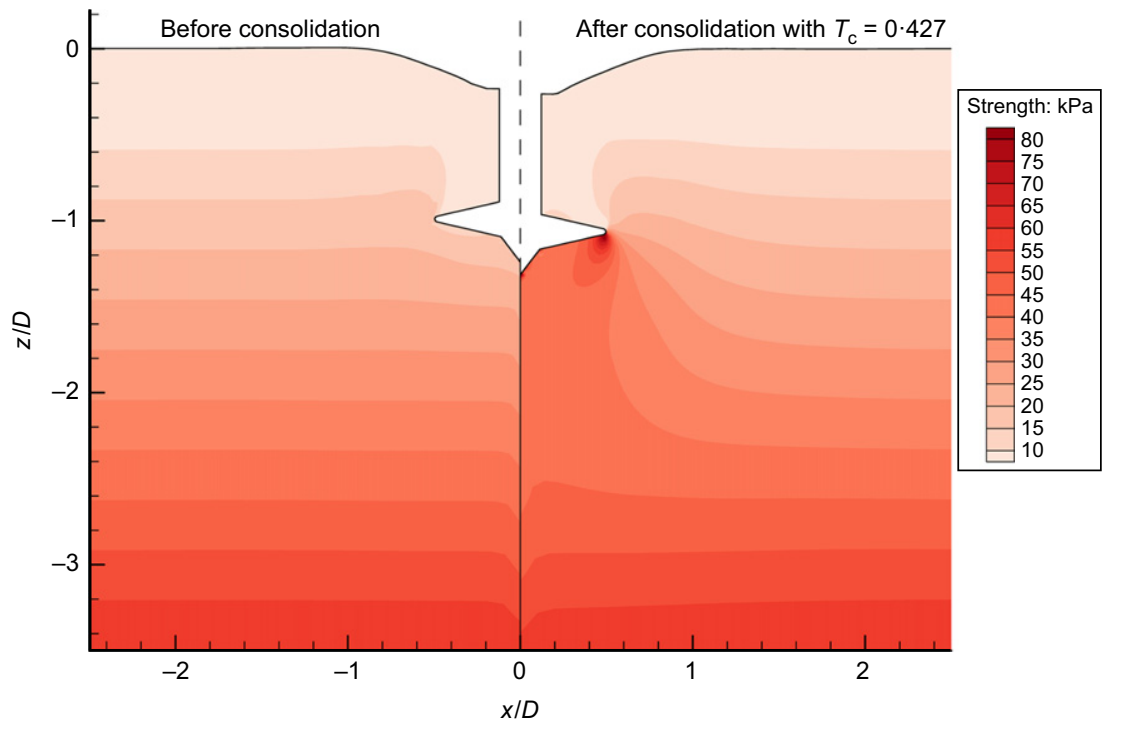

Fig. 8. Undrained shear strength before and after consolidation at consolidation depth $H=1 D$

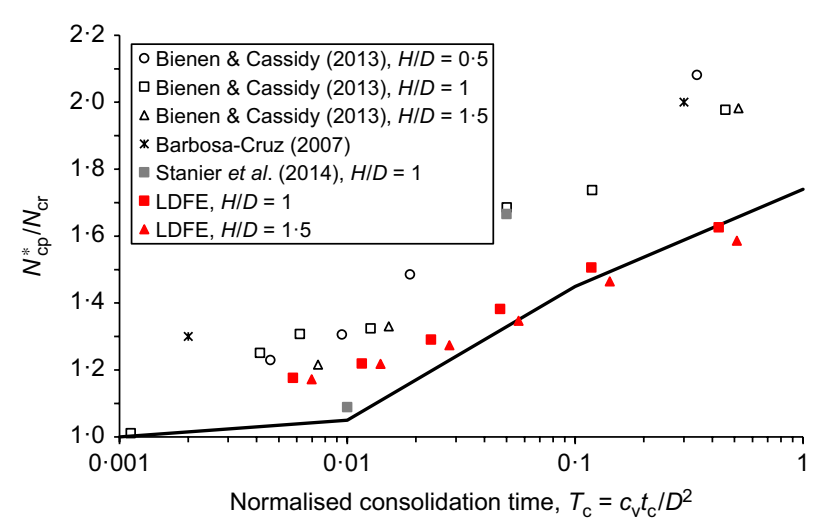

Fig. 9. Enhancement of peak capacity factor with normalised consolidation time (UWA kaolin)

ratios. The horizontal permeability is taken as $k_{\mathrm{h}}=n k_{\mathrm{v}}$ and the permeability ratio, $n$, may be larger than 1 .

The consolidation and further penetration in Malaysian kaolin is simulated, with $n=1$ and $\alpha=1$. Although $c_{\mathrm{v}}$ of Malaysian kaolin is $\sim 10$ times that of UWA kaolin, the peak ratios of both soils are close (Fig. 10), suggesting that the peak ratio in different soils can be approximated as a function of $T_{\mathrm{c}}$. The scenarios with $H / D=1$ in UWA kaolin are repeated with $n=5$. As the dissipation around the spudcan is influenced by both $k_{\mathrm{h}}$ and $k_{\mathrm{v}}$, equation (3) is updated to

$$
T_{\mathrm{c}}=\frac{1+n}{2} \frac{c_{\mathrm{v}} t_{\mathrm{c}}}{D^{2}}
$$

As shown in Fig. 10, the normalised consolidation duration defined in equation (4) quantifies the variation of the peak ratio for $n=1$ and 5 well.

While Figs 7-10 are presented in terms of $\alpha=1$, the peak ratios for $\alpha=0.5$ and 0.75 are demonstrated in Fig. 11. The enhancement of the peak capacity factor increases with the consolidation load ratio at a given $H / D$.

\section{PREDICTION OF POST-CONSOLIDATION RESISTANCE}

A simple procedure is proposed to predict the postconsolidation resistance, with the load ratio of unity as an example (the effect of a load ratio other than unity can be estimated using Fig. 11)

(a) Estimate the consolidation settlement corresponding to a given consolidation duration. The typical settlement can be derived from the numerical curves in Fig. 6. 


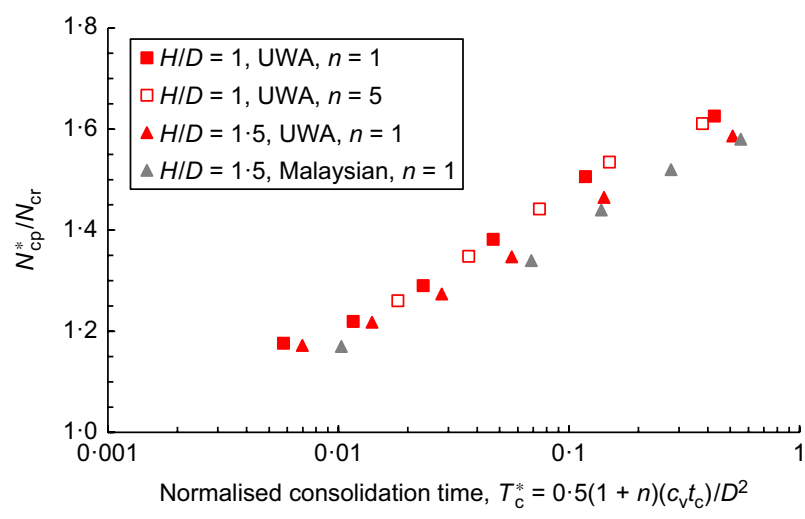

Fig. 10. Variation of peak ratio with normalised consolidation time (load ratio of unity)

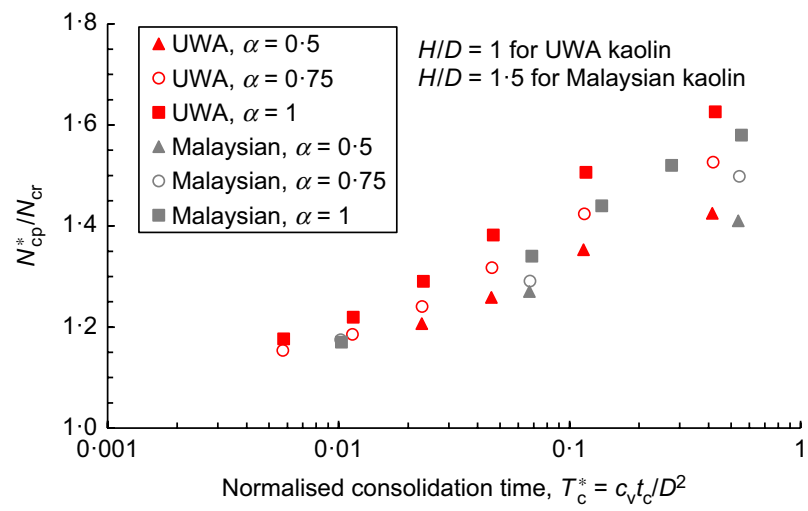

Fig. 11. Peak ratios at different consolidation load ratios (permeability ratio of unity)

(b) Determine the depth over which post-consolidation penetration resistance increases quickly. This penetration distance, $H_{\mathrm{cp}}$, is measured from the end of the consolidation settlement until the appearance of the peak capacity factor $N_{\mathrm{cp}}^{*}$. Although the magnitude of $H_{\mathrm{cp}}$ increases with the consolidation duration, it covers a relatively narrow range. $H_{\mathrm{cp}}$ can be approximated as $0 \cdot 14 D$ for UWA kaolin.

(c) Calculate the penetration resistance within $H_{\mathrm{cp}}$. The resistance within $H_{\mathrm{cp}}$ is simplified as increasing linearly. The resistance at the end of $H_{\mathrm{cp}}$ can be obtained from $N_{\mathrm{cp}}^{*}$ in Fig. 9, fitted conservatively by the polyline.

(d) Calculate the resistance in subsequent penetration. The resistance profile after short-term consolidation moves back to the reference profile quickly (Fig. 7(a)), whereas the profile after long-term consolidation can be approximated as nearly parallel to the reference profile over a limited penetration distance. The resistance profile beyond the peak capacity factor is assumed to be parallel to the reference profile.

The post-consolidation resistances from the simplified method are compared with the LDFE profiles in Fig. 12, in terms of UWA kaolin at $H / D=1$.

\section{CONCLUSIONS}

A simple method is proposed to estimate the postconsolidation penetration resistance of spudcan footings

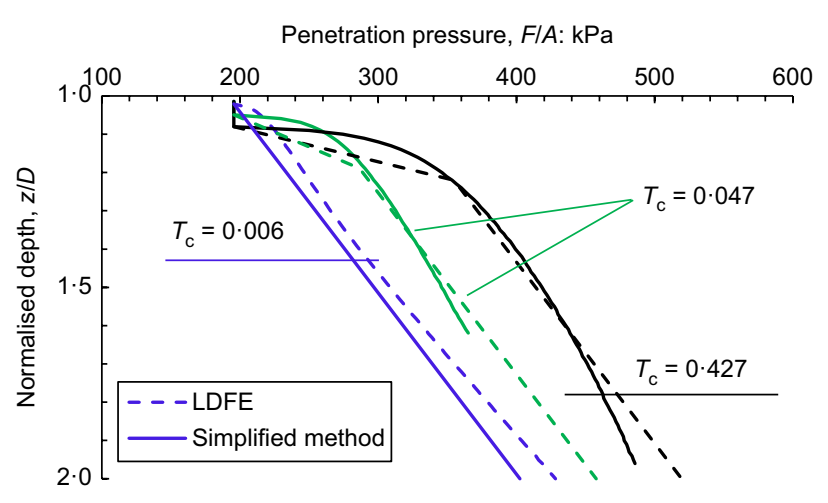

Fig. 12. Post-consolidation penetration resistance predicted by the simplified method

that have experienced a pause during installation. The development is based on results from coupled pore fluid-effective stress large-deformation numerical analyses, with validation against centrifuge experimental data in normally consolidated kaolin clays. The numerical approach allowed the key factors influencing the consolidation-induced zone of increased undrained shear strengths to be investigated in detail.

\section{ACKNOWLEDGEMENTS}

This work forms part of the activities of the Centre for Offshore Foundation Systems (COFS), which is supported by the Lloyd's Register Foundation as a Centre of Excellence and now forms one of the primary nodes of the Australian Research Council (ARC) Centre of Excellence for Geotechnical Science and Engineering. Lloyd's Register Foundation invests in science, engineering and technology for public benefit, worldwide. The research was also supported under Australian Research Council's Laureate Fellowship funding scheme (project number FL130100059). The second author is the recipient of an ARC Postdoctoral Fellowship (DP110101603). The authors are grateful for all of this support.

\section{NOTATION}

$A$ projected area of spudcan

$c_{\mathrm{v}}$ coefficient of consolidation

$D$ diameter of spudcan

e void ratio

$F$ total penetration resistance

$F^{\prime}$ net penetration resistance

$\boldsymbol{g}$ acceleration of gravity

$H$ spudcan depth at beginning of consolidation

$H_{\mathrm{cp}} \quad$ post-consolidation penetration distance to mobilise $N_{\mathrm{cp}}^{*}$

$K_{0}$ coefficient of earth pressure at rest

$k_{\mathrm{h}}, k_{\mathrm{v}}$ horizontal and vertical permeability

$N_{\mathrm{c}}$ bearing capacity factor

$N_{\mathrm{cp}}^{*} \quad$ peak capacity factor post-consolidation

$N_{\text {cr }}$ reference capacity factor

$n$ permeability ratio $\left(=k_{\mathrm{h}} / k_{\mathrm{v}}\right)$

$S_{\mathrm{t}} \quad$ soil sensitivity

$s_{\mathrm{u}} \quad$ undrained shear strength of soil

$T$ normalised consolidation time

$T_{\mathrm{c}}$ normalised consolidation duration

$t$ consolidation time

$t_{\mathrm{c}}$ consolidation duration

$z$ soil depth

$\alpha$ consolidation load ratio

$\sigma_{\mathrm{v}}^{\prime} \quad$ vertical effective stress 


\section{REFERENCES}

Barbosa-Cruz, E. R. (2007). Partial consolidation and breakthrough of shallow foundations in soft soil. $\mathrm{PhD}$ thesis, The University of Western Australia, Crawley, Australia.

Bienen, B. \& Cassidy, M. J. (2013). Set-up and resulting punchthrough risk of jack-up spudcans during installation. J. Geotech. Geoenviron. Engng 139, No. 12, 2048-2059.

Bienen, B., Ragni, R., Cassidy, M. J. \& Stanier, S. (2015). Effects of consolidation under a penetrating footing in carbonate silty clay. J. Geotech. Geoenviron. Engng 141, No. 9, 04015040.

Brennan, R., Diana, H., Stonor, R. W. P., Hoyle, M. J. R., Cheng, C. P., Martin, D. \& Roper, R. (2006). Installing jackups in punch-through sensitive clays. Proceedings of offshore technology conference, Houston, TX, USA, paper OTC 18286.

Hossain, M. S. \& Randolph, M. F. (2009). Effect of strain rate and strain sofening on the penetration resistance of spudcan foundations on clay. Int. J. Geomech. 9, No. 3, 122-132.

ISO (International Organization for Standardization) (2012). ISO/FDIS 19905-1: Petroleum and natural gas industries site-specific assessment of mobile offshore unit-part 1: jack-ups. Geneva, Switzerland: ISO.

Mahmoodzadeh, H., Randolph, M. F. \& Wang, D. (2014). Numerical simulation of piezocone dissipation test in clays. Géotechnique 64, No. 8, 657-666, http://dx.doi. org/10.1680/geot.14.P.011.

Mahmoodzadeh, H., Wang, D. \& Randolph, M. F. (2015). Interpretation of piezoball dissipation testing in clay. Géotechnique 65, No. 10, 831-842, http://dx.doi.org//10.1680/ jgeot.14.P.213

Purwana, O. A. (2006). Centrifuge model study on spudcan extraction in soft clay. $\mathrm{PhD}$ thesis, National University of Singapore, Singapore.

Purwana, O. A., Leung, C. F., Chow, Y. K. \& Foo, K. S. (2005). Influence of base suction on extraction of jack-up spudcans.
Géotechnique 55, No. 10, 741-753, http://dx.doi.org/10.1680/ geot.2005.55.10.741.

Richardson, M. (2007). Rowe cell test on kaolin clay, COFS internal report. Crawley, Australia: The University of Western Australia.

Stanier, S., Ragni, R., Bienen, B. \& Cassidy, M. J. (2014). Observing the effects of sustained loading on spudcan footings in clay. Géotechnique 64, No. 11, 918-926, http://dx.doi.org/10.1680/ geot.14.P.003.

Vessia, G., Casini, F. \& Springman, S. M. (2012). Discussion of paper 'Estimating hydraulic conductivity from piezocone soundings'. Géotechnique 62, No. 10, 955-956, http://dx.doi. org/10.1680/geot.12.D.001.

Wang, D., Hu, Y. \& Randolph, M. F. (2010). Three-dimensional large deformation finite element analysis of plate anchor in uniform clay. J. Geotech. Geoenviron. Engng 136, No. 2, $355-365$.

Wang, D., Merifield, R. S. \& Gaudin, C. (2013). Uplift behaviour of helical anchors in clay. Can. Geotech. J. 50, No. 6, 575-584.

Wang, D., Bienen, B., Nazem, M., Tian, Y., Zheng, J., Pucker, T. \& Randolph, M. F. (2015). Large deformation finite element analyses in geotechnical engineering. Comput. Geotech. 65, 104-114.

Wroth, C. P. (1984). The interpretation of in situ soil tests. Géotechnique 34, No. 4, 449-489, http://dx.doi.org/10.1680/ geot.1984.34.4.449.

Zhang, Y., Wang, D., Cassidy, M. J. \& Bienen, B. (2014). Effect of installation on the bearing capacity of a spudcan under combined loading in soft clay. J. Geotech. Geoenviron. Engng 140, No. 7, 04014029.

Zhou, H. \& Randolph, M. F. (2009). Resistance of full-flow penetrometers in rate-dependent and strain-softening clay. Géotechnique 59, No. 2, 79-86, http://dx.doi.org/10.1680/geot. 2007.00164 